\title{
Short-Term Effects of Kapalbhati Pranayama on Hematological Parameters: A Retrospective Cross-Sectional Study
}

\author{
Baljinder Singh Bal \\ Department of Physical Education, Guru Nanak Dev University, Amritsar, India \\ Tel: 91-828-492-1150_E-mail: bal_baljindersingh@yahoo.co.in
}

Received: March 23, 2015 Accepted: April 23, 2015 Published: April 30, 2015

doi:10.5296/elr.v1i1.7519 URL: http://dx.doi.org/10.5296/elr.v1i1.7519

\begin{abstract}
The primary aim of this research was to determine the short-term effects of Kapalbhati Pranayama on hematological parameters. The research was carried out on a sample of 44 university level girls of Department of Physical Education (T), Guru Nanak Dev University, Amritsar between the age group of 19-25 years (Mean \pm SD: age $21.340 \pm 1.999$ years, height $5.515 \pm 2.156$ feet's, body mass $67.025 \pm 4.625 \mathrm{~kg}$ ). The subjects from Group-A: Experimental were subjected to a 4-week Bhastrika Pranayama. Student $t$ test for paired samples was utilized to compare the means of the pre-test and the post-test. No significant differences were found in Hemoglobin $(\mathrm{Hb})$, Total Cholesterol (TC), Low Density Lipoprotein Cholesterol (LDL-Cholesterol), High Density Lipoprotein Cholesterol (HDL-Cholesterol) and Triglycerides (TG) among University Level Girls.
\end{abstract}

Keywords: Kapalbhati pranayama, Hemoglobin, Total cholesterol, Low density lipoprotein cholesterol, High density lipoprotein cholesterol, Triglycerides

\section{Introduction}

The yogic research and analysis aiming to explore the underneath complexity about the inter-relationship of body, mind \& soul is the crux of the technique of Yoga. The word Yoga is derived from the Sanskrit word 'Yuj' which essentially means to join or unite. The union referred to is that of the individual self uniting with Cosmic Consciousness or the Universal Spirit. In Indian religions, yoga is "the means or techniques for transforming consciousness and attaining liberation (moksha) from karma (Ankerberg, 1996) and rebirth (samsara)" (Bowker, 1997). It is "a practice by means of which a spiritual seeker strives, (1) to control nature to make the soul fit for union with the Oversoul (the true Self or Atman-Brahman or "God"), and (2) to attain union with God and thus the liberation of the soul from the 
rounds of rebirth and death." (Chopra, 2004). Yoga began in India as early as 3000 B.C. according to archeological evidence (Raj, 1994). It emerged in the later hymns of the ancient Hindu texts (Upanishads or Vedanta) (600-500 B.C.).

It is mentioned in the classic Indian poem Mahabharata (400 B.C.-400 A.D.) and discussed in the most famous part of that poem, the Bhagavad Gita. Yoga was systemized by Patanjali in the Yoga Sutras (300-200 B.C.). The Indian sage patanjali prescribed adherence to eight limbs of yoga, aimed at quieting one's mind to achieve the union of mind, body and spiritthe ultimate aim of traditional yoga. These limbs include 'Yama' and 'Niyama' (a code of conduct for an ethical lifestyle), 'Asana' (physical postures), 'Pranayama' (breath control), 'Pratyahara' (withdrawal of the senses from external objects to increase self-awareness), 'Dharana' (concentration), 'Dhyana' (meditation) and 'Samadhi' (oneness with the object of meditation) (Iyengar, 1966; Feuerstein, 1998). Speaking specifically, Yoga therapy is the "process of empowering individuals to progress toward improved health and well-being through the application of the philosophy and practice of Yoga" (Taylor, 2012).

The beneficial effects of different pranayama are well reported and has sound scientific basis (Joshi, Joshi, \& Gokhale, 1992; Bhattacharya, Pandey, \& Verma, 2002). The effect of different pranayamas on healthy (Subbalakshmi, Saxena, Urmimala, \& Urban, 2005) and diseased people (Cooper et al., 2003; Dhungel, Malhotra, Sarkar, \& Prajapati, 2008; Ravindra \& Madanmohan, 2006) has been well studied and they are known to affect the cardiopulmonary activities and autonomic functions. Growing number of evidences have claimed that yoga practices increases longevity, (Bharshankar, Bharshanker, Deshpande, Kaore, \& Gosavi, 2003) has therapeutic (Khanam, Sachdev, Guleria, \& Deepak , 1996) and rehabilitative effects (Katiyar \& Bihari, 2006). Demarcating the scope of present discussion Kapalbhati Pranayama is one of the main pranayamas. Kapalbhati pranayama is a part of series of breathing exercises. It has many benefits and it helps in achieving good health. Thus, this paper investigates the effects of Kapalbhati pranayama on hematological parameters.

\section{Methods}

\subsection{Participants}

Forty Four, university level girls of Department of Physical Education (T), Guru Nanak Dev University, Amritsar between the age group of 19-25 years (Mean \pm SD: age 21.340 \pm 1.999 years, height $5.515 \pm 2.156$ feet's, body mass $67.025 \pm 4.625 \mathrm{~kg}$ ) volunteered to participate in the study. The subjects were purposively assigned into two groups: Group-A: Experimental $\left(\mathrm{n}_{1}=22\right)$; Group-B: Control $\left(\mathrm{n}_{2}=22\right)$. The Distribution and demographics of subjects are presented in Table 1. 


\section{Macrothink}

Table 1. Distribution and demographics of subjects

\begin{tabular}{llll}
\hline \multicolumn{2}{l}{ Sample Size $(\mathbf{N}=\mathbf{4 4})$} & & \\
\hline Variables & Total $(\boldsymbol{N}=44)$ & Experimental group $\left(\boldsymbol{n}_{\boldsymbol{1}}=22\right)$ & Control group $\left(\boldsymbol{n}_{2}=22\right)$ \\
\hline Age & $21.340 \pm 1.999$ & $21.636 \pm 1.989$ & $21.045 \pm 2.011$ \\
Body Height & $5.515 \pm 2.156$ & $5.518 \pm 2.084$ & $5.513 \pm 2.273$ \\
Body Mass & $67.025 \pm 4.625$ & $66.472 \pm 4.518$ & $67.577 \pm 4.770$ \\
\hline
\end{tabular}

\subsection{Procedure}

This study is designed as a retrospective cross-sectional study. The subjects from Group-A: Experimental were subjected to a 4-week Kapalbhati Pranayama. This lasted 4 weeks and consisted of daily sessions. Hemoglobin was determined in the blood samples of all the subjects with the use of a hematology analyzer (Celldyne model 3500). Blood samples (10 ml) for the determination of lipid profiles were obtained. All of biochemical tests have been done with serum samples. Lipid parameters (Triglyceride; Cholesterol; Low-density lipoprotein; High-density lipoprotein) were measured using Boehringer Mannheim kits and Clinilab, BioMerieux analyser as used by (Jastrzebska et al., 2002).

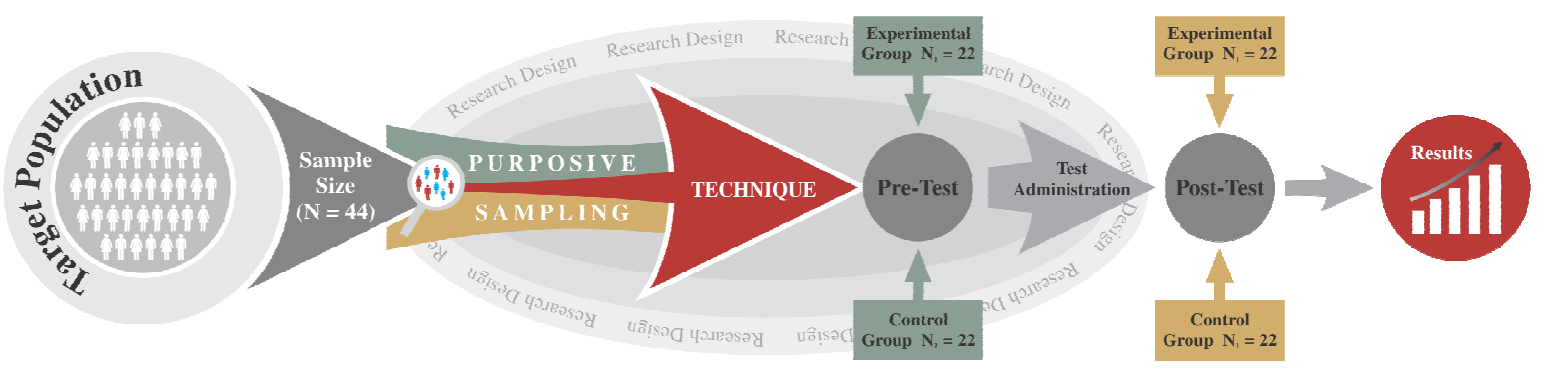

Figure 1. Study design

Table 2. Experimental Treatment

\section{4-Weeks Kapalbhati Pranayama Training}

\begin{tabular}{llll}
\hline Weeks & Schedule & Time & Duration \\
$1^{\text {st }}$ Week & Preliminary Yogic Exercises & 5 Minute & \\
& Practice of Kapalbhati Pranayama & 10 Minute & 20 Minute \\
& $(9$ Rounds $\times 1$ Set $)$ & & \\
& Relaxation Posture & 5 Minute & \\
$2^{\text {nd }}$ Week & Preliminary Yogic Exercises & 5 Minute & 25 Minute \\
& Practice of Kapalbhati Pranayama & 15 Minute & \\
& $(9$ Rounds $\times 2$ Set $)$ & & \\
\hline
\end{tabular}


Relaxation Posture

$3^{\text {rd }}$ Week Preliminary Yogic Exercises

Practice of Kapalbhati Pranayama

(9 Rounds $\times 3$ Set)

Relaxation Posture

$4^{\text {th }}$ Week Preliminary Yogic Exercises

Practice of Kapalbhati Pranayama

(9 Rounds $\times 4$ Set)

Relaxation Posture
5 Minute

5 Minute

20 Minute

30 Minute

5 Minute

5 Minute

25 Minute

35 Minute
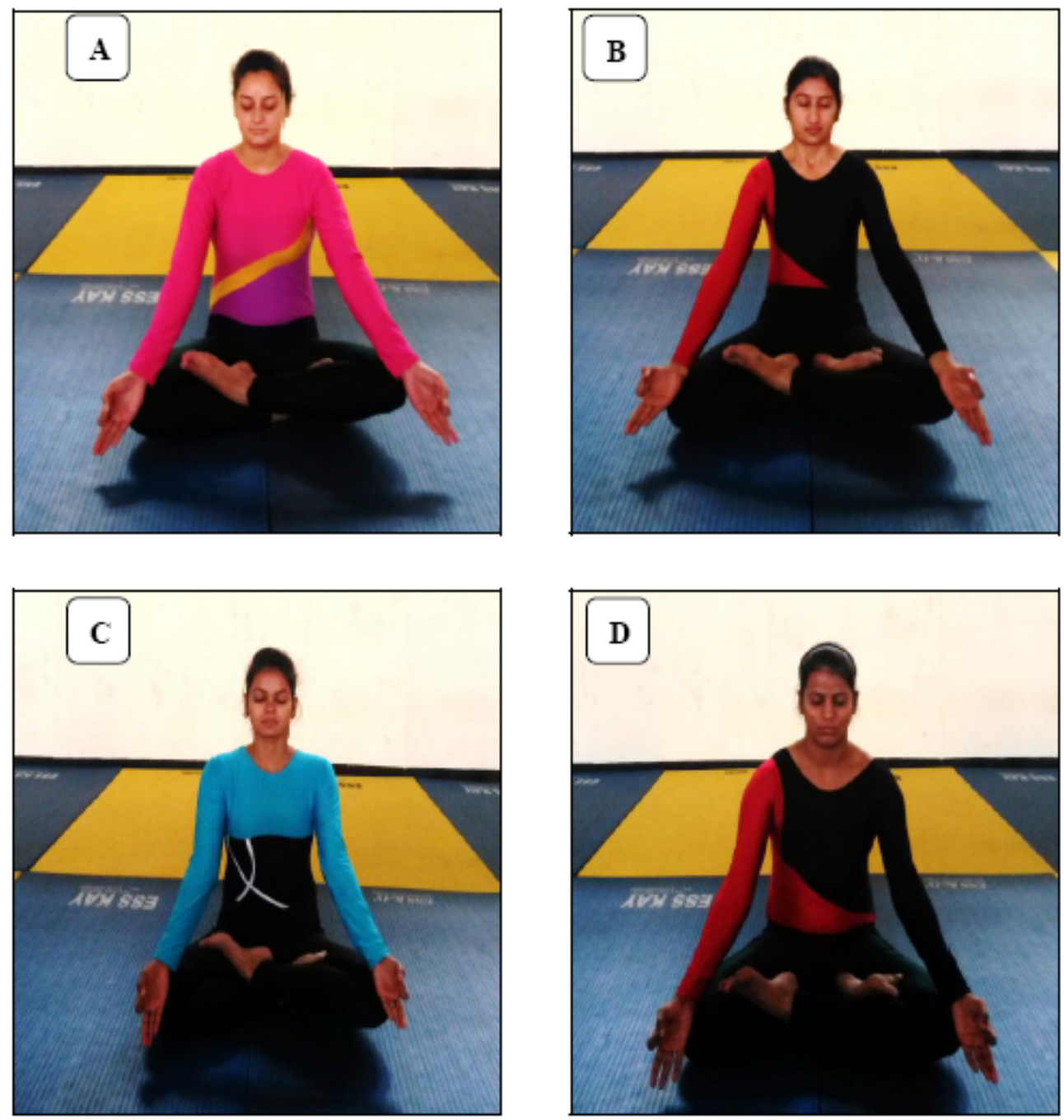

Figure 2. Subject Performing Bhastrika Pranayama 

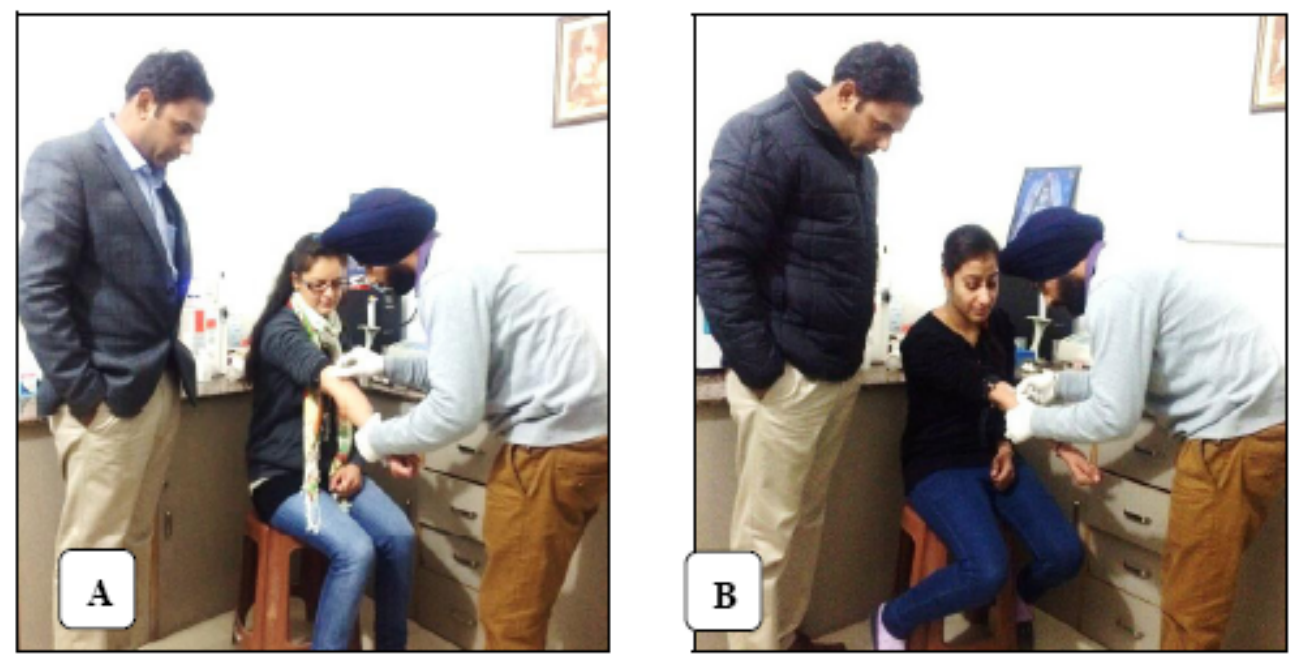

Figure 3. Biochemical tests with serum samples

\section{Statistical Analysis}

Statistical analyses were performed using the Statistical Package for the Social Sciences for Windows version 10.0 software (SPSS Inc., Chicago, IL). Data is expressed as the mean \pm SD. Student $t$ test for paired samples was utilized to compare the means of the pre-test and the post-test. To test the hypothesis, the level of significance was set at 0.05.

\section{Results}

The results of Hematological Parameter (i.e., Hemoglobin (Hb), Total Cholesterol (TC), Low Density Lipoprotein Cholesterol (LDL-Cholesterol), High Density Lipoprotein Cholesterol (HDL-Cholesterol) and Triglycerides (TG) in university level girls are presented in Table 3.

Table 3. Descriptive Statistics (Mean \& Standard Deviation) and Paired Sample t-test of Hematological Parameter (i.e., Hemoglobin (Hb), Total Cholesterol (TC), Low Density Lipoprotein Cholesterol (LDL-Cholesterol), High Density Lipoprotein Cholesterol (HDL-Cholesterol) and Triglycerides (TG) of University Level Girls

\begin{tabular}{lllllll}
\hline Hemoglobin $(\mathbf{H b})$ & & & & & & \\
\hline Group & Number & Mean & $\begin{array}{l}\text { Standard } \\
\text { Deviation }\end{array}$ & $\begin{array}{l}\text { Standard Error } \\
\text { of the Mean }\end{array}$ & t-value & p-value \\
\hline $\begin{array}{l}\text { Experiment } \\
\text { (Pre-test) }\end{array}$ & 22 & 13.336 & 0.678 & 0.144 & 1.299 & 0.208 \\
$\begin{array}{l}\text { Experimental } \\
\text { (Post-test) }\end{array}$ & & 13.363 & 0.663 & 0.141 & & \\
$\begin{array}{l}\text { Control } \\
\text { (Pre-test) }\end{array}$ & 22 & 12.950 & 0.539 & 0.115 & & \\
$\begin{array}{l}\text { Control } \\
\text { (Post-test) }\end{array}$ & 22 & 12.959 & 0.517 & 0.110 & & 0.680 \\
\hline
\end{tabular}


Total Cholesterol (TC)

Experiment

22

(Pre-test)

$156.072 \quad 10.253$

2.186

0.847

0.406

Experimental

(Post-test)

Control 22

$153.222 \quad 10.980$

2.341

0.591

0.560

(Pre-test)

22

$153.236 \quad 10.992$

2.343

Control

(Post-test)

\section{Low Density Lipoprotein Cholesterol (LDL-Cholesterol)}

$\begin{array}{lllllll}\begin{array}{l}\text { Experiment } \\ \text { (Pre-test) }\end{array} & 22 & 113.063 & 6.960 & 1.483 & 0.646 & 0.525 \\ \begin{array}{l}\text { Experimental } \\ \text { (Post-test) }\end{array} & 22 & 113.077 & 6.977 & 1.487 & & \\ \text { Control } & 22 & 116.077 & 6.342 & 1.352 & 0.213 & 0.833 \\ \text { (Pre-test) } & 22 & 116.081 & 6.337 & 1.351 & & \end{array}$

Control

(Post-test)

\section{High Density Lipoprotein Cholesterol (HDL-Cholesterol)}

$\begin{array}{lllllll}\begin{array}{l}\text { Experiment } \\ \text { (Pre-test) }\end{array} & 22 & 67.404 & 3.120 & 0.665 & 1.789 & 0.088 \\ \begin{array}{l}\text { Experimental } \\ \text { (Post-test) }\end{array} & 22 & 67.440 & 3.132 & 0.667 & & \\ \text { Control } & 22 & 70.059 & 4.763 & 1.015 & 1.096 & 0.285 \\ \text { (Pre-test) } & 22 & 70.081 & 4.767 & 1.016 & & \\ \text { Control } & & & & & & \\ \text { (Post-test) } & & & & & & \end{array}$

\section{Triglycerides (TG)}

\begin{tabular}{lllllll}
$\begin{array}{l}\text { Experiment } \\
\text { (Pre-test) }\end{array}$ & 22 & 137.036 & 7.982 & 1.701 & 1.000 & 0.328 \\
$\begin{array}{l}\text { Experimental } \\
\text { (Post-test) }\end{array}$ & 22 & 137.059 & 7.973 & 1.699 & & \\
Control & 22 & 131.904 & 7.711 & 1.644 & 0.204 & 0.840 \\
(Pre-test) & 22 & 131.909 & 7.705 & 1.642 & & \\
Control & & & & & & \\
(Post-test) & & & & & & \\
\hline
\end{tabular}




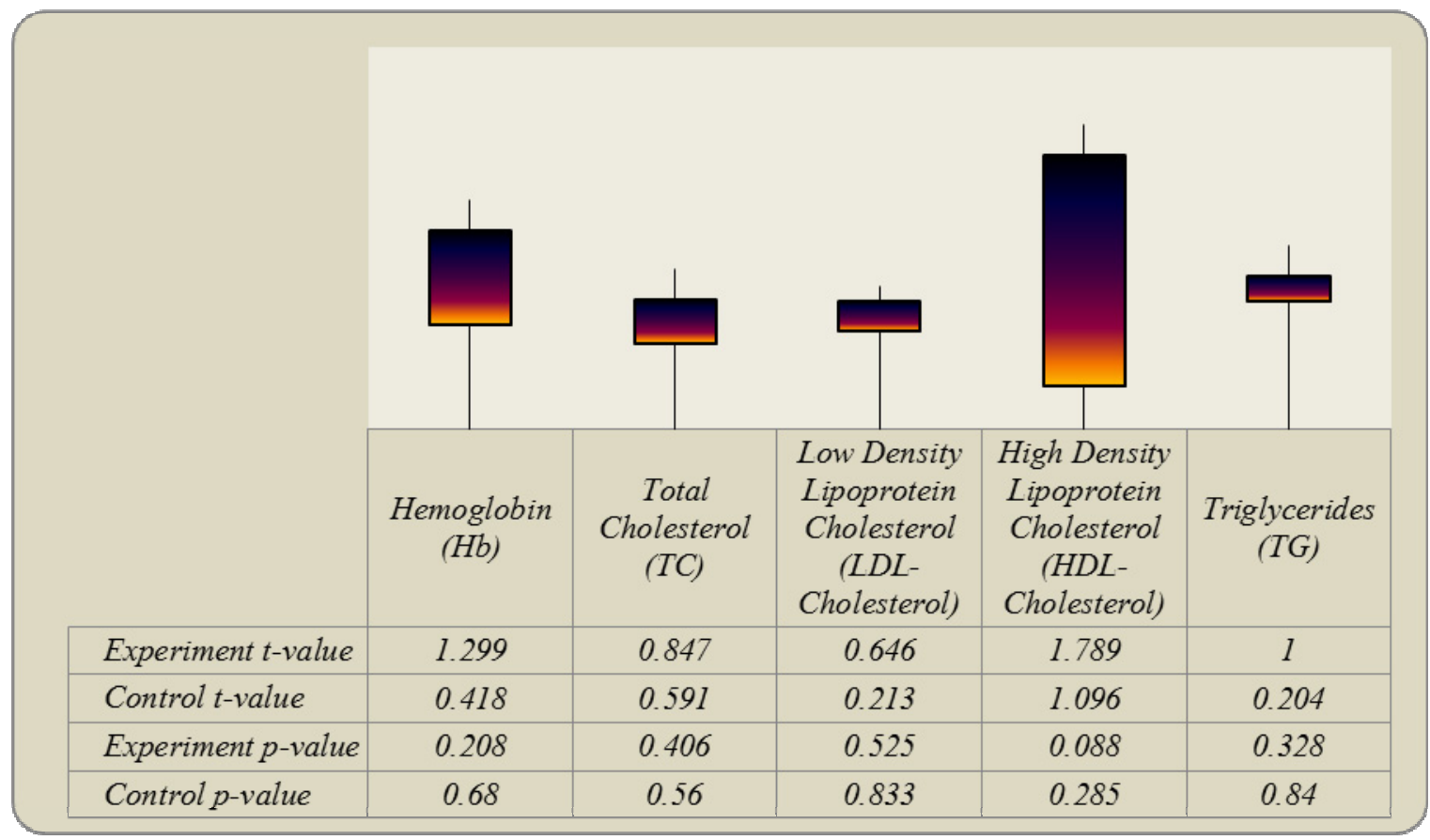

Figure 4. t-value and p-value for the Experimental (Pre-Test \& Post-Test) and Control (Pre-Test \& Post-Test) Groups Scores of Hematological Parameter

\subsection{Hemoglobin $(\mathrm{Hb})$}

The results of Hematological Parameter in group (Experimental) and group (Control) are shown in [Table-3]. The Mean and Standard Deviation values of Hemoglobin ( $\mathrm{Hb})$ of pre-test and post-test of experimental group was $13.336 \pm 0.678$ and $13.363 \pm 0.663$ respectively. However, the Mean and Standard Deviation values of Hemoglobin ( $\mathrm{Hb})$ of pre-test and post-test of control group were $12.950 \pm 0.539$ and $12.959 \pm 0.517$. The t-value in case of experimental group was 1.299 and for control group it was 0.418 .

No significant between-group differences were noted in Hemoglobin $(\mathrm{Hb})$ since the calculated value of $(t=1.299)$ is smaller than tabulated value of $t .05(21)=2.08$ for the selected degree of freedom and level of significance. The data does suggest that the differences between pre-test and post-test of Hemoglobin $(\mathrm{Hb})$ in experimental and control group are insignificant.
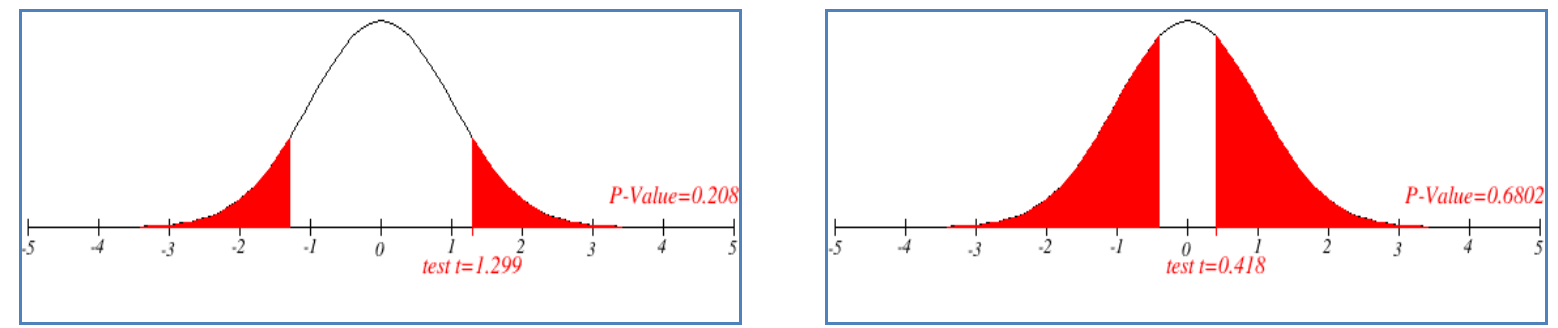

Figure 5. t-test and p-value for the Experimental (Pre-Test \& Post-Test) and Control (Pre-Test $\&$ Post-Test) Groups on the parameter Hemoglobin ( $\mathrm{Hb})$ 


\section{Macrothink}

\subsection{Total Cholesterol (TC)}

The Mean and Standard Deviation values of Total Cholesterol (TC) of pre-test and post-test of experimental group was $156.072 \pm 10.253$ and $156.090 \pm 10.242$ respectively. However, the Mean and Standard Deviation values of Total Cholesterol (TC) of pre-test and post-test of control group were $153.222 \pm 10.980$ and $153.236 \pm 10.992$. The t-value in case of experimental group was 0.847 and for control group it was 0.591 .

No significant between-group differences were noted in Total Cholesterol (TC) since the calculated value of $(\mathrm{t}=0.847)$ is smaller than tabulated value of $t .05(21)=2.08$ for the selected degree of freedom and level of significance. The data does suggest that the differences between pre-test and post-test of Total Cholesterol (TC) in experimental and control group are insignificant.
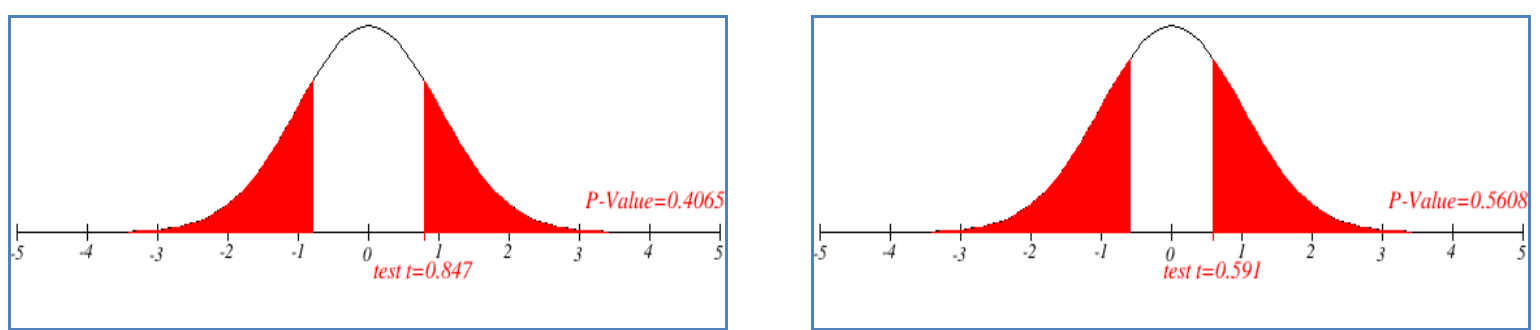

Figure 6. t-test and p-value for the Experimental (Pre-Test \& Post-Test) and Control (Pre-Test $\&$ Post-Test) Groups on the parameter Total Cholesterol (TC)

\subsection{Low Density Lipoprotein Cholesterol (LDL-Cholesterol)}

The Mean and Standard Deviation values of Low Density Lipoprotein Cholesterol (LDL-Cholesterol) of pre-test and post-test of experimental group was $113.063 \pm 6.960$ and $113.077 \pm 6.977$ respectively. However, the Mean and Standard Deviation values of Low Density Lipoprotein Cholesterol (LDL-Cholesterol) of pre-test and post-test of control group were $116.077 \pm 6.342$ and $116.081 \pm 6.337$. The $t$-value in case of experimental group was 0.646 and for control group it was 0.213 .

No significant between-group differences were noted in Low Density Lipoprotein Cholesterol (LDL-Cholesterol) since the calculated value of $(\mathrm{t}=0.646)$ is smaller than tabulated value of t $.05(21)=2.08$ for the selected degree of freedom and level of significance. The data does suggest that the differences between pre-test and post-test of in Low Density Lipoprotein Cholesterol (LDL-Cholesterol) in experimental and control group are insignificant.
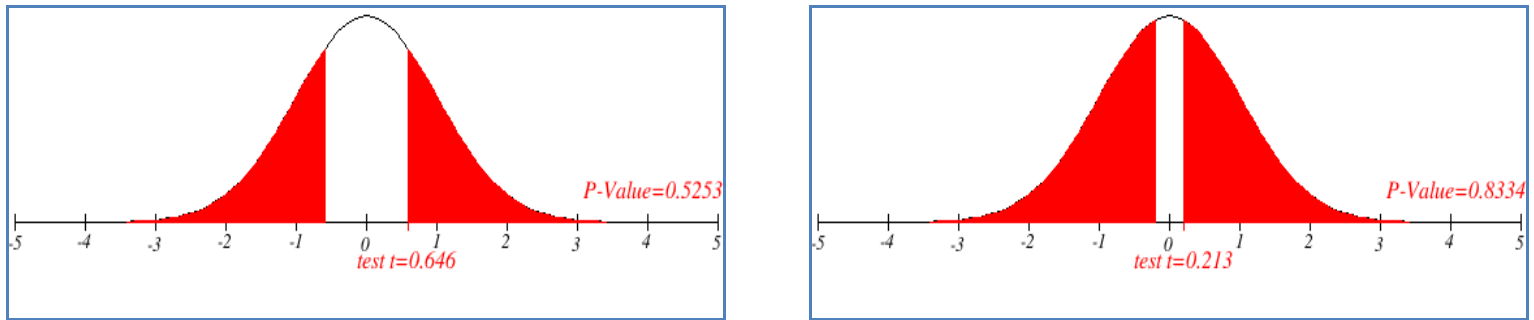

Figure 7. t-test and p-value for the Experimental (Pre-Test \& Post-Test) and Control (Pre-Test \& Post-Test) Groups on the parameter Low Density Lipoprotein Cholesterol (LDL-Cholesterol) 


\section{Macrothink}

\subsection{High Density Lipoprotein Cholesterol (HDL-Cholesterol)}

The Mean and Standard Deviation values of High Density Lipoprotein Cholesterol (HDL-Cholesterol) of pre-test and post-test of experimental group was 67.404 \pm 3.120 and $67.440 \pm 3.132$ respectively. However, the Mean and Standard Deviation values of High Density Lipoprotein Cholesterol (HDL-Cholesterol) of pre-test and post-test of control group were $70.059 \pm 4.763$ and $70.081 \pm 4.767$. The $t$-value in case of experimental group was 1.789 and for control group it was 1.096 .

No significant between-group differences were noted in High Density Lipoprotein Cholesterol (HDL-Cholesterol) since the calculated value of $(t=1.789)$ is smaller than tabulated value of $t_{.05}(21)=2.08$ for the selected degree of freedom and level of significance. The data does suggest that the differences between pre-test and post-test of High Density Lipoprotein Cholesterol (HDL-Cholesterol) in experimental and control group are insignificant.
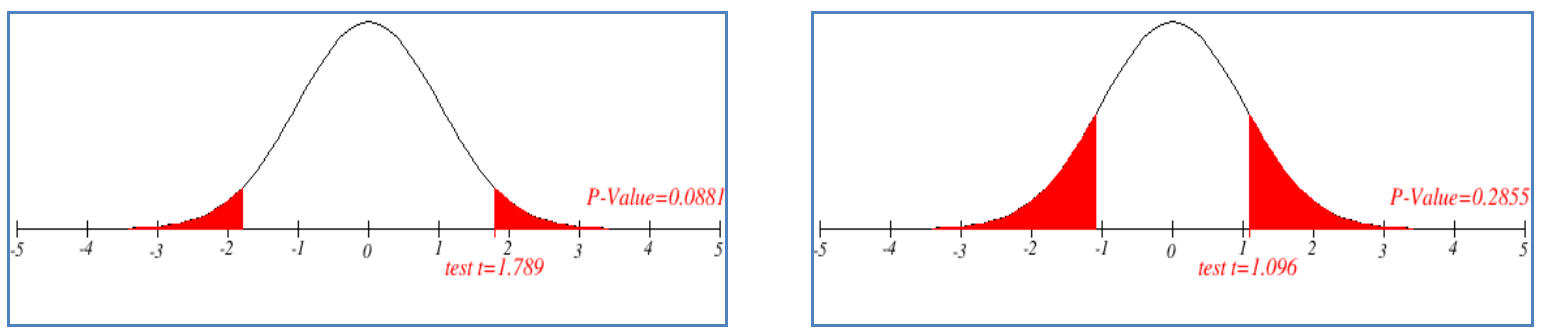

Figure 8. t-test and p-value for the Experimental (Pre-Test \& Post-Test) and Control (Pre-Test $\&$ Post-Test) Groups on the parameter High Density Lipoprotein Cholesterol

(HDL-Cholesterol)

\subsection{Triglycerides (TG)}

The Mean and Standard Deviation values of Triglycerides (TG) of pre-test and post-test of experimental group was $137.036 \pm 7.982$ and $137.059 \pm 7.973$ respectively. However, the Mean and Standard Deviation values of Triglycerides (TG) of pre-test and post-test of control group were $131.904 \pm 7.711$ and $131.909 \pm 7.705$. The $t$-value in case of experimental group was 1.000 and for control group it was 0.204 .

No significant between-group differences were noted in Triglycerides (TG) since the calculated value of $(\mathrm{t}=1.000)$ is smaller than tabulated value of $t .05(21)=2.08$ for the selected degree of freedom and level of significance. The data does suggest that the differences between pre-test and post-test of Triglycerides (TG) in experimental and control group are insignificant. 


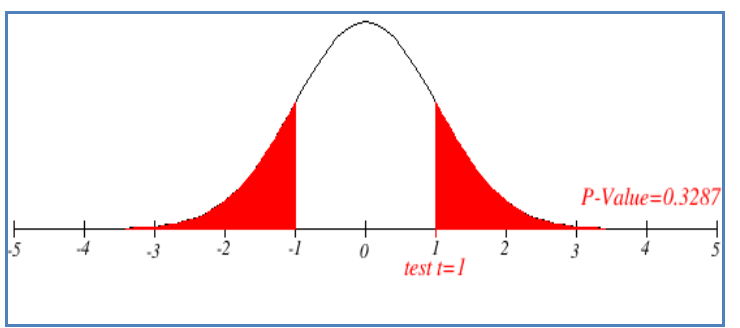

Figure 9. t-test and p-value for the Experimental (Pre-Test \& Post-Test) and Control (Pre-Test \& Post-Test) Groups on the parameter Triglycerides (TG)

\section{Conclusion}

In summary, the current study exhibits an intervening attempt to determine the short-term effects of Kapalbhati pranayama on hematological parameters of university level girls. No significant differences were found in Hemoglobin ( $\mathrm{Hb}$ ), Total Cholesterol (TC), Low Density Lipoprotein Cholesterol (LDL-Cholesterol), High Density Lipoprotein Cholesterol (HDL-Cholesterol) and Triglycerides (TG) of university level girls.

\section{Acknowledgement}

The paper is a fragment of the research done within the project of M.R.P (Minor and Major) sanctioned by University Grants Commission (U.G.C.) New Delhi.

\section{References}

Ankerberg J, (1996). In J. Weldon (Ed.), 'Yoga' in Encyclopedia of New Age Belief. (pp. 593-610). United States: Harvest House Publishers.

Bharshankar, J. R., Bharshanker, R. N., Deshpande, V. N., Kaore, S. B., \& Gosavi, G. B. (2003). Effect of yoga on cardiovascular system in subjects above 40 years. Indian J Physiol Pharmacol, 47(2), 202-06.

Bhattacharya, S., Pandey, U. S., \& Verma, N. S. (2002). Improvement in oxidative status with yogic breathing in young healthy males. Indian J Physiol Pharmacol, 46, 349-54.

Bowker J. (1997). The Oxford Dictionary of World Religions. New York: Oxford University Press. 1058-9.

Chopra D. (2004). The Seven Spiritual Laws of Yoga. In N. J. Hoboken (Ed.), United States: John Wiley and Sons.

Cooper, S., Oborne, J., Newton, S., Harrison, V., Thompson, C. J., Lewis, S., \& Tattersfield, A. (2003). Effect of two breathing exercises (Buteyko and pranayama) in asthma: a randomised controlled trial. Thorax, 64-75. http://dx.doi.org/10.1136/thorax.58.8.674

Dhungel, K. U., Malhotra, V., Sarkar, D., \& Prajapati, R. (2008). Effect of alternate nostril breathing exercise on cardiorespiratory functions. Nepal Med Coll J, 10, 25-27.

Feuerstein, G. (1998). The Yoga Tradition. Prescott: Hohm Press.

Iyengar, B. K. S. (1966). Light on Yoga. New York: Schocken Books.

Jastrzębska, M., Foltyńska, A., Torbus-Lisiecka, B., Chelstowski, K., Pieczul-Mróz, J., \& Klimek, K. (2002). Fibrinogen and von Willebrand factor levels in relation to lipid profile and blood pressure in children whose fathers have a history of premature myocardial infraction. Polish Heart Journal, 56(6), 488-95. 


\section{Macrothink}

Education and Linguistics Research

ISSN 2377-1356 2015, Vol. 1, No. 1

Joshi, L. N., Joshi, V. D., \& Gokhale, L. V. (1992). Effect of short term Pranayama on Ventilatory functions of lung. Indian J Physiol Pharmacol, 36, 105-8.

Katiyar, S. K., \& Bihari, S. (2006). Role of pranayama in rehabilitation of COPD patients - a randomized controlled study. Indian J Allergy Asthma Immunol, 20(2), 98-104.

Khanam, A. A., Sachdev, V., Guleria, R., \& Deepak, K. K. (1996). Study of pulmonary and autonomic functions of asthma patients after yoga training. Indian $J$ Physiol Pharmacol, 40(4), 318-24.

Raj, V. A. (1994). The Hindu Connection: Roots of New Age (pp. 62-86). St. Louis: Concordia Publishing House.

Ravindra, P. N., \& Madanmohan, P. P. (2006). Effect of pranayam (yogic breathing) and shavasan (relaxation training) on the frequency of benign ventricular ectopics in two patients with palpitations. Int J Cardiol, 108, 124-125. http://dx.doi.org/10.1016/j.ijcard.2005.02.023

Subbalakshmi, N. K., Saxena, S. K., Urmimala, D., \& Urban, J. A. (2005). Immediate effect of Nadishodhan Pranayama on some selected parameters of cardiovascular, pulmonary and higher functions of brain. Thai J Physiological Sciences, 18, 10-16.

Taylor, M. (2012). What is Yoga Therapy? An IAYT definition. Yoga therapy in practice.

\section{Copyright Disclaimer}

Copyright reserved by the author(s).

This article is an open-access article distributed under the terms and conditions of the Creative Commons Attribution license (http://creativecommons.org/licenses/by/3.0/). 